\title{
Gangrene of the External Genitalia at the Regional University Hospital Center of Ouahigouya: Epidemiological Profile and Therapeutic Aspects
}

\section{Tiéoulé Mamadou Traore ${ }^{1 *}$, Clôtaire Alexis Marie Kiemdiba Donega Yameogo², Moussa Kabore1, Souleymane Ouedraogo ${ }^{1}$}

\author{
${ }^{1}$ Service de chirurgie du CHU régional de Ouahigouya, Ouahigouya, Burkina Faso \\ ${ }^{2}$ Service d'urologie du CHU Yalgado Ouédraogo Ouagadougou, Ouaga, Ouagadougou, Burkina Faso \\ Email: *t.mamadou.t@gmail.com,t_mamadou@yahoo.fr
}

How to cite this paper: Traore, T.M., Yameogo, C.A.M.K.D., Kabore, M. and Ouedraogo, S. (2020) Gangrene of the External Genitalia at the Regional University Hospital Center of Ouahigouya: Epidemiological Profile and Therapeutic Aspects. Open Journal of Urology, 10, 184-191. https://doi.org/10.4236/oju.2020.106021

Received: March 6, 2020

Accepted: May 10, 2020

Published: May 13, 2020

Copyright $\odot 2020$ by author(s) and Scientific Research Publishing Inc. This work is licensed under the Creative Commons Attribution International License (CC BY 4.0).

http://creativecommons.org/licenses/by/4.0/

\begin{abstract}
Introduction: Gangrene of extern genitary organs is a rapidly progressive necrotizing fasciitis of the perineum and external genitalia that results from a polymicrobial infection. Mortality remains high despite advances in resuscitation. We report the experience of the surgery department of the Regional University Hospital Center (CHUR) of Ouahigouya in order to describe the epidemiological profile and the therapeutic aspects of GOGE. Patients and methods: We carried out a descriptive and analytical retrospective study collecting 41 cases of Fournier's gangrene treated over 63 months (from March 2013 to July 2018) in the surgical department of the Ouahigouya regional university hospital center. Ethical clearance was taken from the institutional ethics committee. Results: The mean age of the patients was $65.02 \pm 17.92$ years with extremes of 23 years and 95 years. All patients were male. Urologic causes were the most common with $36.58 \%$ of cases. The average consultation time was $15.44 \pm 16.04$ days with extremes of 1 day and 60 days. All patients received resuscitation, bi or triantibiotherapy and surgical debridement. The mortality rate was $24.39 \%$. The mean duration of hospitalization was $10.83 \pm 6.257$ days with extremes of 1 day and 60 days. Conclusion: The Fournier's gangrene always has a very high lethality. Improving the prognosis requires fast and effective management.
\end{abstract}

\section{Keywords}

Fournier's Gangrene, Epidemiology, Emergency, Mortality 


\section{Introduction}

Fournier external genitalia gangrene (GOGE) is a rapidly progressive necrotizing fasciitis of the perineum and external genitalia that results from polymicrobial infection [1]. In 1883 a French dermatologist named Jean Alfred Fournier reported five cases of gangrene of the external genitalia with no apparent cause in young men. This disease was called gangrene of Fournier [2]. The source of the infection can be urological, proctological or dermatological. However, in about $5 \%$ of cases GOGE is said to be idiopathic [1]. It is a rare urological emergency that can quickly put life threatening into play. Mortality remains high despite progress in resuscitation. It is estimated between $16 \%$ and $40 \%$ [3]. Management must be rapid and effective [4]. We report the experience of the surgery department of the Regional University Hospital Center (CHUR) of Ouahigouya in order to describe the epidemiological profile and the therapeutic aspects of GOGE.

\section{Patients and Method}

This was a descriptive and analytical retrospective study of 41 patients treated over a period of 63 months (from March 2013 to July 2018) in the surgical department of CHUR Ouahigouya in Burkina Faso. Data were collected from hospital records and patient records. Epidemiological (age, sex, profession), diagnostic (time to consult, clinical examination on admission, biology), therapeutic (resuscitation, antibiotic therapy, debridement) and evolutionary (duration of hospitalization, survival) were studied. The statistical analysis was performed by the Statistical Package for the Social Sciences (SPSS) software in version 21.0. The tests used were Student's $\mathrm{t}$ test and Fisher's exact test. $\mathrm{P}<0.05$ was considered statistically significant. The figures and tables were produced using Excel 2013 software. The confidentiality of the data was respected.

\section{Results}

During the study period, we collected 41 cases of GOGE, an average of 7.8 cases per year. GOGE accounted for $0.54 \%$ (41/7617) of all admissions during the study period. The mean age of the patients was $65.02 \pm 17.92$ years with extremes of 23 and 95 years. Figure 1 shows the distribution of patients by age group. All of the patients were male. Cultivators represented $85.36 \%(35 / 41)$ of the patients.

Table 1 gives the distribution of patients according to the favorable factors. Urological causes were the most frequent with $36.58 \%$ of cases.

Table 2 gives the distribution of patients according to etiologies.

The mean consultation time was $15.44 \pm 16.04$ days with extremes of 1 day and 60 days. The anatomical location of the lesions is given in Table 3.

The most frequent clinical signs were pain and infectious syndrome (100\%), necrotic (47\%) and ulcerative-necrotic lesions (53\%). Ten patients $(24.39 \%)$ experienced septic shock.

Therapeutically, all the patients benefited from resuscitation, bi or triantibio- 
therapy and surgical debridement in the operating room. Antibiotic therapy included a third-generation cephalosporin, an imidazole, and an aminoglycoside if kidney function was good. Only 4 patients required two debridements in the operating room. A suprapubic cystostomy was performed in 4 (9.76\%) patients. No colostomy was performed. Five patients benefited from secondary suturing distant from infectious phenomena.

Postoperative mortality was $24.39 \%$ (10/41). The average age of the deceased patients was 70 years. There was no statistically significant difference between the ages of the survivors and the ages of the deceased $(\mathrm{p}=0.180)$. The average consultation time was 19 days in the deceased versus 14.37 days in the survivors but with no statistically significant difference $(\mathrm{p}=0.455)$. We noted that the mortality rate was higher in patients who had a hemoglobin level lower than 10 $\mathrm{g} / \mathrm{dl}$ compared to those who had a hemoglobin level higher than $10 \mathrm{~g} / \mathrm{dl}(\mathrm{p}=$ 0.008). The mean hospital stay was $10.83 \pm 6.257$ days with extremes of 1 day and 25 days.

Table 4 gives the comparison of clinical and biological elements between the series of mortality and survival.

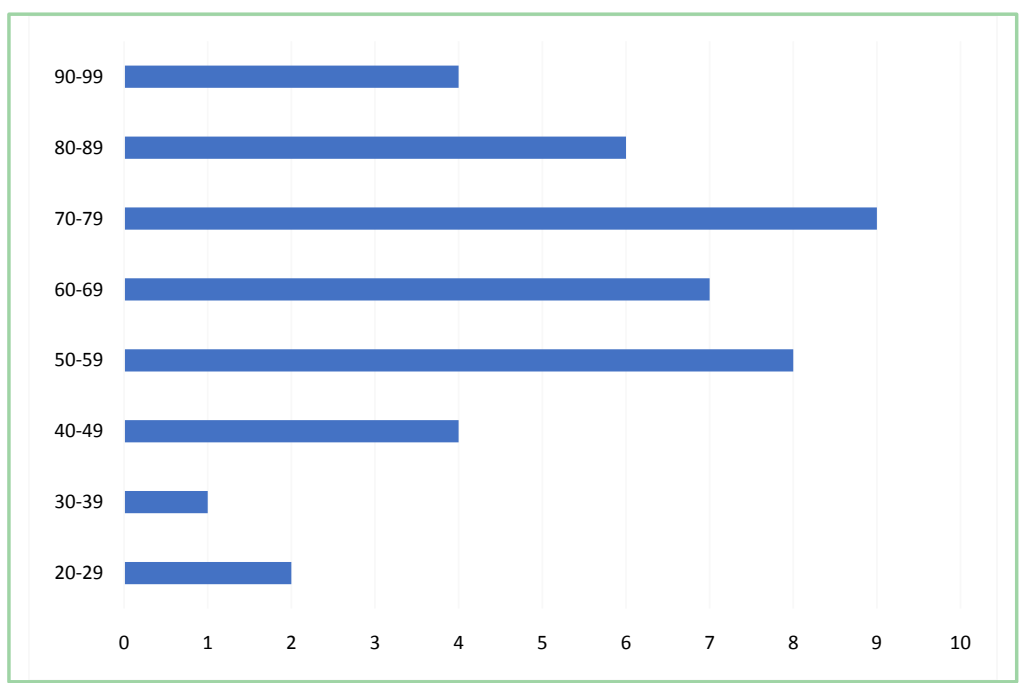

Figure 1. Age distribution of patients.

Table 1. Distribution of patients according to the risk factors.

\begin{tabular}{ccc}
\hline Risk factors & Effective & Percentage (\%) \\
\hline HBP & 9 & 22 \\
Paraplegia & 4 & 9.8 \\
Diabetes & 2 & 4.9 \\
HIV & 1 & 2.4 \\
Sickle cell anemia & 1 & 2.4 \\
Renal failure & 1 & 2.4 \\
Idiopathic & 23 & 56.1 \\
Total & 41 & 100 \\
\hline
\end{tabular}

HBP: Hight Blood Pressuer, HIV: Human Immuno-defiency virus. 
Table 2. Distribution of patients according to etiologies.

\begin{tabular}{cccc}
\hline Etiologies & & Effectif & Percentage \\
\hline & Scrotal abscess & 3 & 4.88 \\
Urological (36.58\%) & Infected hydrocele & 4 & 9.75 \\
& Urethral stenosis & 4 & 7.32 \\
& Benign prostatic hyperpasia & 3 & 4.88 \\
Proctological (4.88\%) & Bladder tumor & 1 & 2.44 \\
& Perianal abscess & 2 & 4.88 \\
Iatrogenic (12.20\%) & Post-prostatic adenomectomy & 2 & 4.88 \\
& Post-hydrocelectomy & 3 & 7.32 \\
Traumatic (2.44\%) & Scrotal trauma & 1 & 2.44 \\
Dermatological (14.63\%) & Bedsores & 4 & 9.76 \\
No cause found (29.27\%) & Scrotal boil & 2 & 4.88 \\
Total & & 12 & 29.27 \\
& & 41 & 100 \\
\hline
\end{tabular}

Table 3. Distribution of patients according to the extent of the lesions.

\begin{tabular}{ccc}
\hline location of lesions & Effective & Percentage (\%) \\
\hline Scrotum & 25 & 61 \\
Perineo-scotal & 8 & 19.5 \\
Penis & 3 & 7.3 \\
Scrotum and penis & 4 & 9.8 \\
pubis & 1 & 2.4 \\
Total & $\mathbf{4 1}$ & 100 \\
\hline
\end{tabular}

Table 4. Comparison of clinical and biological elements between survivors and deceased.

\begin{tabular}{cccc}
\hline & Survivants $\mathbf{N}=\mathbf{3 1}$ & Décédés $\mathbf{N}=\mathbf{1 0}$ & Valeur $\mathbf{p}$ \\
\hline Age & $63.42( \pm 16.39)$ & $70.00( \pm 22.24)$ & 0.319 \\
Consultation period & $14.37( \pm 15.27)$ & $19( \pm 18.93)$ & 0.455 \\
Septic shock & $7.5 \%$ & $17.5 \%$ & 0.001 \\
Duration of hospitalization & $9.90( \pm 5.31)$ & $13.70(8.25)$ & 0.096 \\
Comorbidities present & $48.39 \%$ & $16.67 \%$ & 0.467 \\
Hemoglobin level & & & \\
$<10$ g/dl & & $50 \%$ & 0.008 \\
$>10$ g/dl & & $9.09 \%$ & \\
Creatinine & $160.16( \pm 155.78)$ & $214.98( \pm 128.91)$ & 0.355 \\
\hline
\end{tabular}

\section{Discussion}

In our series the GOGE hospital frequency was $0.54 \%$. In the United States Sorensen estimated its frequency to be less than $0.02 \%$ [5]. In the Kambou series in Burkina Faso, the GOGE represented $2.3 \%$ of hospitalizations [6]. In other words, it is a rare condition. However, the most important series come from developing countries [1].

All of our patients were male. Indeed, GOGE is known to be a condition which mainly affects the male subject. Most studies on the issue point to the 
clear male dominance [7] [8] [9]. This is explained by the fact that in women there is better drainage of the perineal region through the vaginal secretions [1] [10] [11]. Yücell, on the other hand, reports in its series a female predominance at $56 \%[12]$.

GOGE was initially described by Jean Alfred Fournier as an affection of the young subject. But nowadays there is a change in the age of onset of this condition which reaches 61.7 years in certain series [13]. This would be linked to the increase in life expectancy. The average age of our patients was $65.65 \pm 17.69$ years with extremes of 23 and 95 years. Our study effectively confirms this evolution in the epidemiology of GOGE. Older age has been reported as a factor of poor prognosis in GOGE [14] [15]. In our series, however, we did not find a statistically significant difference between the age of the survivors and that of the deceased $(p=0.180)$.

In our series, high blood pressure was the most common comorbidity with $22 \%$ of cases. In addition, there were two cases of diabetes and one case of infection with the human immunodeficiency virus. What is decisive in these comorbidities is the decrease in cellular immunity which thus promotes infection [9]. However, there was no statistically significant difference between the survivors and the deceased concerning the presence or not of co-morbidity $(\mathrm{p}=0.467)$. Four patients were paraplegic in our series. Spinal cord injured people are three times more likely to develop GOGE during their lifetime due to pressure ulcers and chronic urethral catheterization [10].

The three major etiological groups in GOGE are urogenital, proctological and dermatological [1] [9]. In our series gangrene without recognized cause represented $29.27 \%$ of cases. This high rate of gangrene without recognized cause could be explained by the lack of means of exploration in our context. Indeed, nowadays a cause is almost always identified in the GOGE [16]. Urological causes predominated in our series with $36.58 \%$ of cases. Fall in Senegal found a similar result [14]. We noted 5 cases (12.19\%) of iatrogenic GOGE following a hydrocelectomy (3 cases) and a transvesical prostatic adenectomy ( 2 cases). Our result is higher than that of Ersay in Turkey who reported 2.9\% postoperative gangrene in his series [17].

The mean consultation time for the deceased (19 days) was higher than that for the survivors (14.37 days), but the difference was not statistically significant $(\mathrm{p}=0.455)$. Lujan Marco in Spain made the same observation [2]. However, some have established that rapid management is a good prognostic factor in GOGE [18]. Unfortunately, as Ruiz-Tovar pointed out, the period of consultation does not depend on the medical profession [19]. In our context, populations rarely consult health structures in the first place.

GOGE is a urological emergency whose treatment consists of a therapeutic tripod: resuscitation, triple antibiotic therapy and surgical debridement [20]. All our patients benefited from surgical debridement after resuscitation and bi or tri-antibiotic therapy. A first aggressive debridement often avoids a second intervention in the operating room [3]. 
GOGE's prognosis remains poor despite improved resuscitation facilities. Mortality varies between $16 \%$ and $40 \%$ and can go up to $80 \%$ in certain series [3] [8]. The mortality rate in our series was $24.39 \%$. This means that about a quarter of our patients die. This result is clearly higher than that of Kambou, who noted a mortality rate of 5.5\% [6]. This could be explained by the long consultation period in our series but also and above all by an inadequate resuscitation linked to the lack of biological explorations. There is still controversy as to the factors that influence mortality in GOGE [17]. Several prognostic factors have been reported. These include advanced age, diabetes, delay in treatment, and certain biological parameters [15] [19]. We were unable to establish prognostic scores in our series due to the unavailability of biochemical examinations in our health structure. This is a limiting factor in the correction of hydro-electrolytic disorders of our patients. However, we were able to demonstrate that the presence of septic shock as well as anemia was factors of poor prognosis in our series. Indeed, we noted that the mortality rate was higher in patients who had a hemoglobin level lower than $10 \mathrm{~g} / \mathrm{dl}$ compared to those who had a hemoglobin level higher than $10 \mathrm{~g} / \mathrm{dl}(\mathrm{p}=0.008)$. Ruiz-Tovar has shown that the risk of dying is 9.6 times higher if the hemoglobin level is less than $10 \mathrm{~g} / \mathrm{dl}$ [19].

We did not find a statistically significant link between the survivors and the deceased with regard to serum creatinine $(\mathrm{p}=0.072)$. Unlike our study, several studies have shown that elevated serum creatinine is associated with high mortality [4] [19].

\section{Conclusion}

GOGE still has very high lethality. Contrary to the initial description made by Jean Alfred Fournier, GOGE occurs today at an advanced age in patients with low immunity. Several factors determine its prognosis. But in our context, it is mainly the delayed diagnosis which seems to be the main factor. Thus, health education as well as an improvement of the technical platform with a resuscitation service will improve the prognosis of this condition.

\section{Conflicts of Interest}

The authors declare no conflicts of interest regarding the publication of this paper.

\section{References}

[1] Sarkis, P., Farranc, F., Khoury, R., Kamel, G., Nemr, E., Biajini, J. and Merheje, S. (2009) Gangrène de Fournier: Revue de la littérature récente. Progrès en Urologie, 19, 75-84. https://doi.org/10.1016/j.purol.2008.09.050

[2] Luján Marco, S., Budía, A., Di Capua, C., Broseta, E. and Jiménez Cruz, F. (2010) Evaluation of a Severity Score to Predict the Prognosis of Fournier's Gangrene. BJU International, 106, 373-376. https://doi.org/10.1111/j.1464-410X.2009.09075.X

[3] Katib, A., Al-Adawi, M., Dakkak, B. and Bakhsh, A. (2013) A Three-Year Review of the Management of Fournier's Gangrene Presented in a Single Saudi Arabian Insti- 
tute. Central European Journal of Urology, 66, 331-334.

https://doi.org/10.5173/ceju.2013.03.art22

[4] Altarac, S., Katušin, D., Crnica, S., Papeš, D., Rajković, Z. and Arslani, N. (2012) Fournier's Gangrene: Etiology and Outcome Analysis of 41 Patients. Urologia Internationalis, 88, 289-293. https://doi.org/10.1159/000335507

[5] Sorensen, M.D. and Krieger, J.N. (2016) Fournier's Gangrene: Epidemiology and Outcomes in the General US Population. UIN, 97, 249-259. https://doi.org/10.1159/000445695

[6] Kambou, T., Ouattara, A., Paré, A., Kirakoya, B., Kaboré, F.A., Dogo, H., et al. (2017) External Genitalia Gangrene: Clinical, Therapeutic Aspects and Prognosis at University Hospital Souro Sanou of Bobo Dioulasso (Burkina Faso). Open Journal of Urology, 7, 235. https://doi.org/10.4236/oju.2017.712028

[7] Rimtebaye, K., Niang, L. and Ndoye, M. (2014) Gangrène de Fournier: Aspects épidémiologique, clinique, diagnostique et thérapeutique au service d'urologie de N'djamena. Revue Africaine d' Urologie et d'Andrologie, 1. http://www.revue-uroandro.org/index.php/uro-andro/article/view/4

[8] Kuzaka, B., Wróblewska, M., Borkowski, T., Kawecki, D., Kuzaka, P., Młynarczyk, G., et al. (2018) Fournier's Gangrene: Clinical Presentation of 13 Cases. Medical Science Monitor, 24, 548-555. https://doi.org/10.12659/MSM.905836

[9] Eke, N. (2000) Fournier's Gangrene: A Review of 1726 Cases. British Journal of Surgery, 87, 718-728. https://doi.org/10.1046/j.1365-2168.2000.01497.x

[10] Yılmazlar, T., Işık, Ö., Öztürk, E., Özer, A., Gülcü, B. and Ercan, İ. (2014) Fournier’s Gangrene: Review of 120 Patients and Predictors of Mortality. Ulusal Travma ve Acil Cerrahi Dergisi, 20, 333-337. https://doi.org/10.5505/tjtes.2014.06870

[11] Ettalbi, S., Benchamkha, Y., Boukind, S., Droussi, H., Ouahbi, S., Soussou, M., et al. (2013) La gangrène périnéoscrotale: Profil épidémiologique et aspects thérapeutiques. À propos de 45 cas. Annales de Chirurgie Plastique Esthétique, 58, 310-320. https://doi.org/10.1016/j.anplas.2011.02.002

[12] Yücel, M., Özpek, A., Başak, F., Kılıç, A., Ünal, E., Yüksekdağ, S., et al. (2017) Fournier's Gangrene: A Retrospective Analysis of 25 Patients. Ulusal Travma ve Acil Cerrahi Dergisi, 23, 400-404. https://doi.org/10.5505/tites.2017.01678

[13] Ozden Yeniyol, C., Suelozgen, T., Arslan, M. and Riza Ayder, A. (2004) Fournier's Gangrene: Experience with 25 Patients and Use of Fournier's Gangrene Severity Index Score. Urology, 64, 218-222. https://doi.org/10.1016/j.urology.2004.03.049

[14] Fall, B., Fall, A.P., Diao, B., Kpatcha, T.M., Sow, Y., Kabore, F., et al. (2009) Les gangrènes des organes génitaux externes: A propos de 102 cas. Andrologie, 19, 45-49. https://doi.org/10.1007/s12610-008-0003-x

[15] Sabzi Sarvestani, A., Zamiri, M. and Sabouri, M. (2013) Prognostic Factors for Fournier's Gangrene; A 10-Year Experience in Southeastern Iran. Bulletin of Emergency and Trauma, 1, 116-122.

[16] Sorensen, M.D., Krieger, J.N., Rivara, F.P., Broghammer, J.A., Klein, M.B., Mack, C.D., et al. (2009) Fournier's Gangrene: Population Based Epidemiology and Outcomes. Journal of Urology, 181, 2120-2126. https://doi.org/10.1016/j.juro.2009.01.034

[17] Ersay, A., Yilmaz, G., Akgun, Y. and Celik, Y. (2007) Factors Affecting Mortality of Fournier's Gangrene: Review of 70 Patients. ANZ Journal of Surgery, 77, 43-48. https://doi.org/10.1111/j.1445-2197.2006.03975.x

[18] Tuncel, A., Aydin, O., Tekdogan, U., Nalcacioglu, V., Capar, Y. and Atan, A. (2006) 
Fournier's Gangrene: Three Years of Experience with 20 Patients and Validity of the Fournier's Gangrene Severity Index Score. European Urology, 50, 838-843.

https://doi.org/10.1016/j.eururo.2006.01.030

[19] Ruiz-Tovar, J., Córdoba, L. and Devesa, J.M. (2012) Prognostic Factors in Fournier Gangrene. Asian Journal of Surgery, 35, 37-41.

https://doi.org/10.1016/j.asjsur.2012.04.006

[20] Chennamsetty, A., Khourdaji, I., Burks, F. and Killinger, K.A. (2015) Contemporary Diagnosis and Management of Fournier's Gangrene. Therapeutic Advances in Urology, 7, 203-215. https://doi.org/10.1177/1756287215584740 